Reprinted with permission from: Weed Science. 1983. 31(6):866-873.

Published and copyrighted by: Weed Science Society of America. http://www.wssa.net

\title{
A nursery study of leafy spurge (Euphorbia spp.) complex from North America ${ }^{1}$
}

\author{
DUANE H. EBKE and MELVIN K. MCCARTY
}

The authors work in the Agric. Tech., Dep. Agron, Univ. of Nebraska, and Res. Agric. U.S. Dep. Agric., Agric. Res. Serv., Lincoln, NB 68583, respectively.

\begin{abstract}
:
Live root material of leafy spurge (Euphorbia spp.) was collected from 38 locations across northern United States, southern Canada, and from 1 location in Austria. These materials were established in a nursery at Lincoln, Nebraska along with E. agraria M. Bieb, and E. cyparissias L. \#² EPHCY. Nineteen vegetative and reproductive characters, taken from various taxonomic keys, were measured on plants established for a period of 3 years. Data were compared with previous taxonomic keys of Euphorbia species. A key developed by A. Radcliffe-Smith was used to separate the nursery entries. Leaf width measurements were the most useful taxonomic criteria. Five morphologically separable taxa were observed: $E \times$ pseudovirgata (Schur) Soó, E. esula L. \# EPHES, E. uralensis Fisch. ex Link., E. agraria M. Bieb, and E. cyparissias L.
\end{abstract}

\section{Additional index words:}

Euphorbia $\times$ pseudovirgata, E. esula, E. uralensis, E. cyparissias, plant vatiation, taxonomy, EPHCY, EPHES, weed nursery.

\footnotetext{
${ }^{1}$ Received for publication January 17, 1983 and in revised form June 3, 1983. contribution from U.S. Dep. Agric., Agric. Res. Serv., and the Nebraska Agric. Exp. Stn. Published as Paper No. 7035, J. Series, Nebraska Agric. Exp. Stn. Work reported was conducted under Project 12-94, Nebraska Agric. Exp. Stn.

${ }^{2}$ WSSA-approved computer code from Important Weeds of the World, $3^{\text {rd }}$ ed., 1983. Available from WSSA, 309 West Clark St., Champaign, IL 61820.
} 


\section{Introduction}

An early record of leafy spurge (Euphorbia esula L.) in the United States was in 1827 from a plant collected at Newbury, Massachusetts (3). A plant collected by John H. Redfield at Greenwich Point, Philadelphia, in 1877 was attributed to dumping of ships' ballast. Batho (2) reported its introduction into southwestern Minnesota in a bushel of oats brought from southern Russia in 1890. Another plant was collected by Neils Hanson at Brookings, South Dakota in 1912. Bakke (1) states that in Manitoba the weed is particularly abundant on the land farmed by Russian Mennonites. Dunn (8) concluded that leafy spurge infestations are a result of multiple introductions into the United States. By 1933, leafy spurge had spread from coast to coast and had been reported in 19 states (11). Occurrence of leafy spurge increased to 30 states and could be found in every province of Canada except Newfoundland by 1975 (7).

For many years botanists, agronomists, and taxonomists have repeatedly examined various herbarium specimens of leafy spurge from North America and compared them with their European counterparts. Some have classified the variable specimens as $\mathbf{E u}$ phorbia esula L., while others have recognized many separate and distinct species. Thus, the lists of descriptions and binomials include many entries.

Since leafy spurge is a prime candidate for biological control, it is necessary that we identify the realm of the "esula complex" in North America. The objectives of the experiment were to: a) eliminate environmental factors and observe live specimens in a nursery situation, b) compare taxonomic keys in order to identify which characteristics were descriptive only and which were of taxonomic value, and c) key the plants in the nursery using Radcliffe-Smith's ${ }^{3}$ description of the subsection of the genus Euphorbia that includes the esula complex.

\section{Previous taxonomical evaluation}

Morton (13) viewed the North American population as Euphorbia virgata Wald. \& Kit. Wheeler (16) viewed the same material as Euphorbia esula L., and Radcliffe-Smith referred to it as E. waldsteinii (Sojak) A. Radcliffe-Smith comb. Nov. (14).

Hanson and Rudd (11) accepted the use of E. virgata Wald. \& Kit. On the authority of many taxonomists. E. virgata leaves were described as broadest at or below the middle and were not serrulate. The involucre glands were pronouncedly horseshoe shaped. In $E$. esula the leaves were described as sometimes serrulate and broadest near the apex. The involucre glands were more concave.

Morton (13) used a different approach to distinguish E. esula from E. virgata. In E. esula the horns of the glands of the cyathium were shorter than the width of the gland and were neither denticulate nor enlarged at the apex. The leaves were broadest above the middle, narrowed at the base, and usually subserrulate near the apex. In E. virgata the

${ }^{3}$ Personal communication.

Page 2 of 14 
horns were as long as or longer than the width of the gland, enlarged at the apex, and the larger ones denticulate on the margins. The leaves were broadest below the middle, not narrowed at the base and had an acute apex. He also described plants on the Atlantic seaboard as E. virgata forma esulifolia Thell.

Bakke (1) reviewed several keys and determined that the main differences used to separate E. virgata and E. esula were the shape of the leaves that subtend the umbel, shape of the glands of the cyathium, and shape of the cauline leaves. Upon examining plants of the Midwest Bakke found these characters to be highly variable even on the same plant. He concluded, "The differentiating characters merge into each other to the point where the two species, E. virgata and E. esula, cannot be differentiated".

Groh (10) placed more attention on the point of attachment of the leaf to the stem. In E. esula "the allegedly, but not always actually, narrower lower portion of the leaf does usually become attenuate to a little petiole at the base". In E. virgata this sometimesbroader lower portion is carried through to a rounded, sessile, almost clasping base. Groh (10) stated, "The actual outline of the leaf depends on the width of the leaves and not all leaves are consistent on the same plant". Using the criterion of basal leaf shape, he keyed 50 or so American specimens to E. esula. Sometime later he found a stand of leafy spurge which seemed to have all the characteristics of E. virgata.

Croizat (5) stated, "The great majority if not the totality of the plants known to American agronomists and taxonomists as E. esula L. and E. virgata Wald. \& Kit. Are in reality E. intercedens Podp." Croizat was later informed that E. intercedes Podp. was a homonym of E. intercedens Pax. (6) which made E. intercedens Podp. illegitimate. Croizat thus proposed Euphorbia podperae Croiz. nom. nov. and said, "This name may be used for reference by American taxonomists and other botanists, with the immediate assurance that it can be connected to specimens deposited in a well known herbarium of the United States".

Moore (12) found no collections matching the isotype of E. podperae. He viewed the populations of leafy spurge as highly variable and classified them as E. esula L. sensu lato.

Richardson (15) studied the genus Euphorbia of Kansas, Nebraska, and South and North Dakota. He divided the genus Euphorbia into four subgenera: Chamaesyce, Agaloma, Poinsettia, and Esula. In the subgenus Esula, four species were described: $E$. spathulata Lam., E. podperae Croiz., E. cyparissias L., and E. robusta (Engelm.) Small. E. spathulata was keyed out having cylindrical papillae on the ovary and capsule while the other species had smooth ovaries and capsules. In E. podperae, the style and stigma of an immature, exerted ovary were described as very long and equaling or exceeding the immature capsule in length. E. cyparissias and E. robusta had styles and stigmas of the immature ovary which were short and did not exceed the immature capsule in length.

Dunn and Radcliffe-Smith (9) examined 28 herbarium specimens of leafy spurge collected from 12 states. Upon examination of the specimens, five plant types were distinguishable: E. esula L. sensu stricto, E. esula L. sensu lato, E. virgata Wald. \& Kit. var. uralensis (Fisch. ex Link.) Boiss., E. virgata Wald. \& Kit. var. orientalis Boiss., E. × pseudo virgata (Schur) Soó. Shape of the cauline leaves was the main criterion used in separating the taxa. E. esula L. sensu stricto was separated from the other taxa having 
leaves which were oblanceolate, rounded at the apex, broadest above the middle, usually 0.3-1.0 cm wide, and cuneate-attenuate at the base. E. virgata Wald. \& Kit. var. uralensis had stems that were usually branched from the base. The cauline leaves were oblong to elliptic-oblong with an obtuse or rounded apex in E. esula L. sensu lato. In E. × pseudovirgata (Schur) Soó, the leaves were linear to lanceolate or oblong-lanceolate, broadest at the middle, tapered toward the apex, and somewhat narrowed toward the base. E. virgata Wald. \& Kit. var. orientalis had leaves that were lanceolate, broadest below the middle, rounded to cuneate rounded at the base, usually obtuse but sometimes mucronulate. They concluded that there were multiple introductions of leafy spurge into North America and the present populations were made up of several taxa.

Radcliffe-Smith later recognized these entities as E. esula L., E. androsaemifolia Willd. (as E. esula L. s.1.), E. boissieriana (Woron.) Prokh. (as E. virgata var. orientalis Boiss.), E. uralensis Fisch. ex Link. [as E. virgata var. uralensis (Fisch. ex Link.) Boiss.], and E. $\times$ pseudovirgata (Schur) Soó. Radcliffe-Smith developed a key which included species and hybrids either reported by Croizat $(5,6)$ or by Dunn and Radcliffe-Smith (14). He pointed out that $E$. $\times$ pseudovirgata is the prevalent plant of the Midwest while E. waldsteinii (E. virgata Wald. \& Kit.) did not appear to be as serious a pest as the hybrid.

\section{Materials and methods}

Plastic irrigation pipe $25 \mathrm{~cm}$ in diameter was cut into approximately $1.5-\mathrm{m}$ lengths. The tubes were buried vertically in the soil, leaving 5 to $7 \mathrm{~cm}$ of freeboard above the soil line. These were placed $1.5 \mathrm{~m}$ apart and arranged in five rows with 16 tubes/row. Soil was then replaced in the tubes and tamped to simulate normal bulk density.

Live crown root material of leafy spurge was obtained from different locations across the United States, Canada, and Austria (Table 1). Early samples were received in the summer of 1977 while others arrived into 1980. Two samples from each location were transplanted in adjacent tubes in the row to better observe any variability, which may exist from the same source. Plants were initially watered when transplanted. After establishment rainfall provided the only source of water. No fertilizer was ever added.

Observations began in the spring of 1979 on those plants that were transplanted in 1978. Only characteristics of height and number of stems per tube were recorded on plants in their first year of growth. In 1980, 29 morphological characteristics were measured on plants established 2 years. This number was reduced to 19 characteristics for measurement in 1981 on plants established 2 or 3 years.

Characteristics were measured when the plant reached its full height and seed capsules were approaching maturity. Two mature stems were randomly selected within each tube. These were measured for height from the soil line to the base of the inflorescence and then cut at the soil line. Plants were then brought into the laboratory where characteristics were measured and recorded. Plants were pressed and dried in an oven at $40^{\circ} \mathrm{C}$ for approximately 36 hours and stored in a herbarium cabinet.

Page 4 of 14 
The cyathium, which consists of the male and female organs, the glands, and the stipe, was collected at two stages of development; before the stamens had emerged and when the capsule approached maturity but had not dehisced. Both stages were preserved in ethyl alcohol and glacial acetic acid $(3: 1, \mathrm{v} / \mathrm{v})$.

Table 1. Leafy spurge nursery entry sources, number of years in nursery, and individual contributors.

\begin{tabular}{|c|c|c|c|c|c|}
\hline Tube $^{a}$ & Origin & County & Town & Years & Contributor \\
\hline$\overline{1-2}$ & Aust & North Austria & Krems & 3 & Mandan Nursery \\
\hline $3-4$ & Aust & North Austria & Krems & 3 & Mandan Nursery \\
\hline $5-6$ & ID & Butte & Arco & 3 & Aaron York \\
\hline $7-8$ & ID & Washington & Weiser & 3 & Fred Edminston \\
\hline $9-10$ & WY & Crook & Devils Tower & 3 & Ron Vore \\
\hline $11-12$ & SD & Pennington & Rapid City & 1 & Dan Noble \\
\hline $13-14$ & Sask & ... & Sask. Beach & 3 & M. Molloy \\
\hline $15-16$ & Man & $\ldots$ & Franklin & 3 & Dale Brad \\
\hline $17-18$ & ID & Fremont & St. Anthony & 3 & Russell Hillman \\
\hline $19-20$ & IA & Delaware & Manchester & 3 & Ken Hall \\
\hline $21-22$ & IA & Monona & Turin & 3 & Kyle Peterson \\
\hline $23-24$ & IA & Monona & Turin & 3 & Kyle Peterson \\
\hline $25-26$ & $\mathrm{BC}$ & $\ldots$ & Kamloops & 3 & R.S. Cranston \\
\hline $27-28$ & Sask & $\ldots$ & Jameson & 3 & Peter Harris \\
\hline $29-30$ & Man & $\ldots$ & Sifton & 2 & Gerald Logeot \\
\hline $31-32$ & IA & Monona & Moorhead & 2 & M. K. McCarty \\
\hline $33-34$ & $\mathrm{KS}$ & Shawnee & Topeka & 3 & Mandan Nursery \\
\hline $35-36$ & MI & Kalaska & Kalaska & 3 & Gary Schultz \\
\hline $37-38$ & MN & Hennepin & Shakopee & 3 & O. E. Strand \\
\hline $39-40$ & $\mathrm{NE}$ & Dawes & Chadron & 3 & M. K. McCarty \\
\hline $41-42$ & $\mathrm{NE}$ & Wheeler & Bartlet & 2 & Tim Lambert \\
\hline $43-44$ & $\mathrm{NE}$ & Lancaster & Lincoln & 2 & Duane Ebke \\
\hline $45-46^{\mathrm{b}}$ & MD & Baltimore & Beltsville & 2 & S.W.T. Batra \\
\hline $47-48$ & NY & Lawrence & Massena & 1 & S.W.T. Batra \\
\hline $49-50$ & NV & Elko & North Fork & 3 & P.C. Martinell \\
\hline $51-52$ & NV & Humbolt & Paradise Valley & 3 & P.C. Martinell \\
\hline $53-54$ & ND & Ransom & Sheldon & 3 & Cal Messersmith \\
\hline $55-56$ & ND & Ransom & Sheldon & 3 & Cal Messersmith \\
\hline $57-58$ & WY & Crook & Devils Tower & 2 & Dan Noble \\
\hline $59-60^{c}$ & $\mathrm{NE}$ & Jefferson & Harbine & 2 & Duane Ebke \\
\hline $61-62$ & WY & Crook & Devils Tower & 2 & Dan Noble \\
\hline $63-64$ & MT & Glacier & Glacier Park & 2 & Peter Fay \\
\hline $65-66$ & ND & Morton & Mandan & 3 & Larry Morrow \\
\hline $67-68$ & OR & Baker & Baker & 3 & Dennis Isaacson \\
\hline $69-70$ & OR & Union & LaGrande & 3 & Dennis Isaacson \\
\hline $71-72$ & UT & Cache & Logan & 3 & Louis Jenson \\
\hline $73-73$ & $\mathrm{NE}$ & Madison & Meadow Grove & 2 & Henry Kumpost \\
\hline $75-76$ & NY & Tompkins & Ithaca & 1 & Russ Hahn \\
\hline $77-78$ & MT & Glacier & Glacier Park & 1 & Peter Fay \\
\hline
\end{tabular}

${ }^{a}$ Containers in which acquistions were planted.

${ }^{\mathrm{b}}$ Euphorbia cyparissias.

${ }^{c}$ Euphorbia agraria. 
A Stereo Zoom ${ }^{4}$ dissecting microscope with a micrometer disc inserted in one eyepiece was used for measuring the small floral parts. The young, developing cyathium was dissected and the stamens were counted. The older, more mature cyathium was used for measuring capsule length and width, horn length and width, stipe length, and stigma and style length. As plants reached further maturity, seeds were collected and measured for length and width.

Leaf bracts, located just below the cyathium, were randomly selected on the plant and measured for length and width. Whorled leaves were counted and average measures of length and width were recorded. Leaves at the midcauline point were measured for length and apical, middle, and basal widths. Apical and basal measurements were made $1 \mathrm{~cm}$ from each end of the leaf. Middle measurements were made at the midpoint. Number of leaves were counted for a distance of $4 \mathrm{~cm}$ at the midcauline point to indicate the leafiness of the plant.

Terminal rays were counted and the length of the rays was measured from the base to first pair of bracts and the average recorded. Axillary rays in the uppermost part of the stem were counted. Sterile branches were distinguished from the axillary rays and counted.

Two additional species were added to the nursery for comparison with other entries. E. cyparissias was received from Maryland and E. agraria was collected from southeastern Nebraska. Since these species were easily identifiable, characteristics were not measured.

Some characters measured in 1980 were dependent on stage of development while others were highly variable. These characteristics were omitted from analysis in 1981.

Data collected in 1980 and 1981 were analyzed using standard statistical procedures and were compared with previous taxonomic keys on Euphorbia species. The key most recently developed by Radcliffe-Smith (14) was the most useful in separating and describing the nursery entries.

\section{Results and discussion}

Plant growth in the nursery began earlier each year from 1979 through 1981. Plants were first noticed to emerge and have a green appearance April 1 in 1979, March 21 in 1980, and February 21 in 1981. Increased vigor coupled with warmer winter temperatures in 1979 to 1980 and 1980 to 1981 may account for the earlier emerging plants in 1980 and 1981.

Plants were observed under three different establishment periods. Those transplanted in 1978 represent 3-years establishment, plants transplanted in 1979 represent 2-years establishment, and plants transplanted in 1980 represent 1 year of establishment.

\footnotetext{
${ }^{4}$ Bausch \& Lomb, Rochester, NY 14602. Use of trade name does not constititute or imply an endorsement by the U.S. Dep. of Agric.
}

Page 6 of 14 
Plant heights and number of stems per tube increased significantly each year (Table 2). Stem counts averaged 14.5 stems/tube in first year plants, more than doubled that in year two with 36.2 stems/tube, and again more than doubled in year three with 85 stems/tube. There was almost a six-fold increase in stem number from year one to year three.

Table 2. Average plant height and number of stems of leafy spurge plants in successive years in the nursery ${ }^{\mathrm{a}}$.

\begin{tabular}{ccc}
\hline Period in nursery & Height & Stems \\
\hline$(\mathrm{yr})$ & $(\mathrm{mm})$ & $($ no. $)$ \\
1 & $362 \mathrm{a}$ & $14.5 \mathrm{a}$ \\
2 & $590 \mathrm{~b}$ & $36.2 \mathrm{~b}$ \\
3 & $637 \mathrm{c}$ & $85.0 \mathrm{c}$
\end{tabular}

${ }^{a}$ Means within a column followed by the same letter are not significantly different at the $5 \%$ level using Duncan's multiple range test.

When averaged over all plants, plant height, number of terminal rays, and number of axillary rays were greatest in plants established 3 years. Seed characteristics were consistent from year two to year three. Other characteristics were generally lower in 3-year-old plants than 2-year-old plants.

Gland characteristics observed in the nursery material in 1980 were highly variable, and no patterns could be established. Gland lengths and widths averaged 1.1 and $1.8 \mathrm{~mm}$, respectively, with a range of 0.8 to $1.9 \mathrm{~mm}$ and 1.3 to $2.4 \mathrm{~mm}$, respectively. Horn lengths and widths averaged 0.6 and $0.2 \mathrm{~mm}$, respectively, with a range of 0.3 to $0.9 \mathrm{~mm}$ and 0.1 to $0.4 \mathrm{~mm}$, respectively. Although Morton (13) placed considerable emphasis on these floral characteristics, the very minute parts of the gland and the high degree of variability, which existed in the same plant, made them unreliable as criteria to distinguish differences between species.

The ratio of stigma length and style length to the length of the immature capsule, as used by Richardson (15), seemed to have little value. Since any time before dehiscence would be considered an immature capsule, it would be difficult to collect for this measurement. Of the immature capsules collected, this measurement varied with the maturity of the capsule. Stigma lengths and style lengths averaged 0.6 and $2.2 \mathrm{~mm}$, respectively, while fully developed capsules prior to dehiscence averaged $3.8 \mathrm{~mm}$. All ratios of stigma plus style length to capsule length were less than 1 for all observations and averaged 0.7. This would mean that the stigma plus style was shorter than the capsule length. Richardson's key classified plants having stigma plus style lengths less than the capsule length to be either E. cyparissias or E. robusta. This would be the wrong conclusion. Richardson viewed dried, mounted specimens from various herbaria in his study, whereas fresh material was collected and preserved in this study. This indicated that drying can alter the appearance of the plant and should be taken into account when classifying plants. 
Other measurements taken in 1980 and omitted in 1981 were the number of branches occurring on the stem, length of the stipe of the capsule, and number of whorled leaves subtending the inflorescence. Many of these were dependent on plant maturity and location on the plant or were so highly variable that no conclusions could be made.

Groh (10) placed considerable emphasis on the attachment of the lower portion of the leaf to the stem. Leaves generally were not consistent throughout the plant but when leaves were examined at the midcauline point, more consistency was observed. The lower portion of the leaf which Groh pointed out seemed to be a usable taxonomic criterion.

Measurements of all characteristics of each location were consistent from year to year, except the number of terminal rays on plants established both 2 and 3 years. Ranges and averages of characteristics of locations established for 2 and 3 years are given in Tables 3 and 4 . Twenty-five locations had been established 3 years.

The general leafiness of all plants was very similar, averaging 4.5 leaves $/ 4 \mathrm{~cm}$ of stem except tube numbers 49 and 50 from Nevada, which averaged 7.5, leaves over 2 years of observations. The number of axillary rays was greater than the number of terminal rays for each location, with plants in tube numbers 55 and 56 being relatively the same with 10.3 terminal rays and 10.0 rays.

Table 3. Average of 19 characteristics of leafy spurge from measurements taken after 2 and 3 years in the nursery. Data are from 25 locations.

\begin{tabular}{|c|c|c|}
\hline Characteristics & Range & Mean \\
\hline & 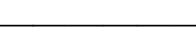 & 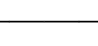 \\
\hline No. of stems & $16.0-217.0$ & 37.1 \\
\hline No. leaves $/ 4 \mathrm{~cm}$ stem length & $3.3-9.0$ & 4.5 \\
\hline No. terminal rays & $7.8-24.8$ & 11.4 \\
\hline No. of axillary rays & $7.5-27.8$ & 17.0 \\
\hline No. of stamens & $4.5-21.0$ & 14.6 \\
\hline Plant height & $472.5-860.0$ & 623.0 \\
\hline Leaf length & $36.0-83.5$ & 61.2 \\
\hline Apical leaf width & $3.0-6.8$ & 5.0 \\
\hline Middle leaf width & $3.8-10.3$ & 6.6 \\
\hline Basal leaf width & $2.3-7.8$ & 5.0 \\
\hline Bract length & $6.5-13.8$ & 10.5 \\
\hline Bract width & $11.8-24.0$ & 16.1 \\
\hline Capsule length & $3.3-4.3$ & 3.8 \\
\hline Capsule width & $4.0-5.0$ & 4.5 \\
\hline Seed length & $2.2-2.7$ & 2.5 \\
\hline Seed width & $1.4-2.0$ & 1.7 \\
\hline Mean length terminal rays & $25.5-71.3$ & 40.9 \\
\hline Mean length whorled leaves & $7.3-29.3$ & 15.0 \\
\hline Mean width whorled leaves & $3.0-13.0$ & 6.7 \\
\hline
\end{tabular}


The overall average for the number of stamens per cyathium was 14.6. Three locations averaged below 10 stamens in 2 years of observations. Tube numbers 13 and 14 from Saskatchewan averaged 7.8 stamens, 15 and 16 from Manitoba averaged 4.9 stamens, and 69 and 70 from Oregon averaged 5.5 stamens.

Plant height and leaf length was not useful criteria because of year-to-year changes. Leaf length and the three leaf width measurements gave a very good indication of the general shape of the leaves. Bract lengths and widths varied in size but the same general appearance existed among the locations between bract length and bract width. Bract widths were generally 4 to $6 \mathrm{~mm}$ greater than bract lengths for each location.

Capsule lengths and widths and seed lengths and widths averaged 3.8 and $4.5 \mathrm{~mm}$ and 2.5 and $1.7 \mathrm{~mm}$, respectively. The mean length of terminal rays averaged $40.9 \mathrm{~mm}$. All locations averaged within $9 \mathrm{~mm}$ of the overall average except the Kansas location, tube numbers 33 and 34, which averaged $60.9 \mathrm{~mm}$. The average lengths of the whorled leaves many times corresponded to the lengths of the midcauline leaf. The Kansas location measured $13 \mathrm{~mm}$ longer than the overall average for all leaf lengths. In comparison, whorled leaves from Kansas measured almost $10 \mathrm{~mm}$ greater than the overall average for whorled leaf lengths. Many of the whorled leaf widths, on the other hand, were greater than the widths from the midcauline leaf.

Table 4. Average values of vegetative and seed characteristics of plants of the leafy spurge complex from various locations for the combined second and third year of establishment.

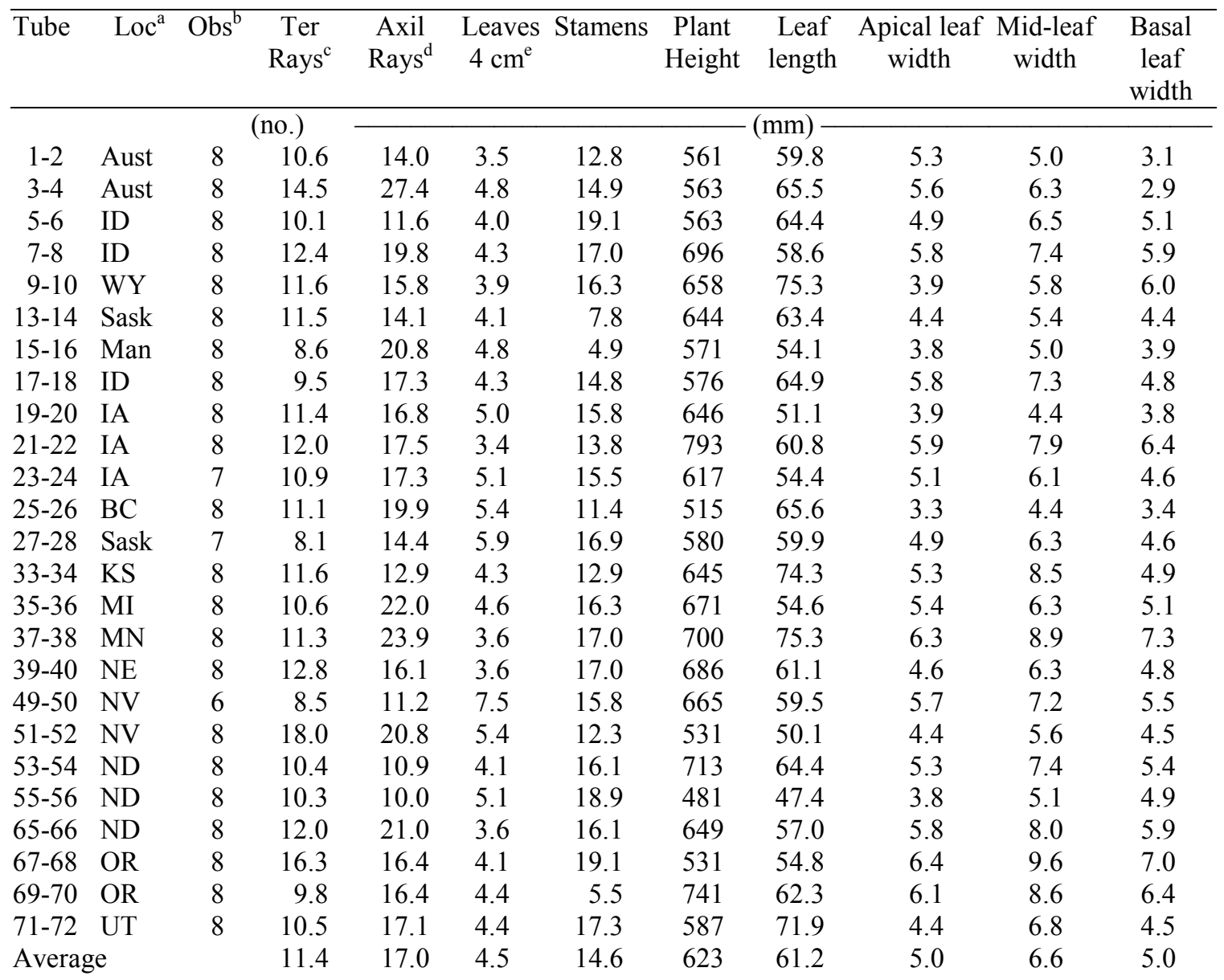


Table 4. (continued)

\begin{tabular}{|c|c|c|c|c|c|c|c|c|c|c|c|}
\hline Tube & $\operatorname{Loc}^{\mathrm{a}}$ & $\mathrm{Obs}^{\mathrm{b}}$ & $\begin{array}{l}\text { Mean } \\
\text { length } \\
\text { ter rays }\end{array}$ & $\begin{array}{c}\text { Mean } \\
\text { length } \\
\text { whorled } \\
\text { leaves }\end{array}$ & $\begin{array}{c}\text { Mean } \\
\text { width } \\
\text { whorled } \\
\text { leaves }\end{array}$ & $\begin{array}{l}\text { Bract } \\
\text { length }\end{array}$ & $\begin{array}{l}\text { Bract } \\
\text { width }\end{array}$ & $\begin{array}{l}\text { Capsule } \\
\text { length }\end{array}$ & $\begin{array}{c}\text { Capsule } \\
\text { width }\end{array}$ & $\begin{array}{c}\text { Seed } \\
\text { length }\end{array}$ & $\begin{array}{l}\text { Seed } \\
\text { width }\end{array}$ \\
\hline $1-2$ & Aust & 8 & 49.6 & 18.6 & 2.9 & 11.8 & $\begin{array}{c}-(\mathrm{mm}) \\
16.5\end{array}$ & 4.6 & 4.8 & 2.5 & 1.8 \\
\hline $3-4$ & Aust & 8 & 41.1 & 7.8 & 3.6 & 7.3 & 11.0 & 3.6 & 4.1 & 2.3 & 1.5 \\
\hline $5-6$ & ID & 8 & 43.8 & 18.5 & 6.5 & 11.3 & 18.1 & 4.0 & 4.4 & 2.6 & 1.6 \\
\hline $7-8$ & ID & 8 & 43.4 & 13.9 & 7.0 & 10.0 & 16.1 & 3.3 & 4.3 & 2.2 & 1.7 \\
\hline $9-10$ & WY & 8 & 43.6 & 16.8 & 5.0 & 10.1 & 15.4 & 3.9 & 4.7 & 2.6 & 1.7 \\
\hline $13-14$ & Sask & 8 & 37.8 & 14.8 & 7.6 & 9.4 & 15.8 & 3.6 & 4.5 & 2.5 & 1.7 \\
\hline $15-16$ & Man & 8 & 41.5 & 13.1 & 4.4 & 11.1 & 17.5 & 3.9 & 4.7 & 2.4 & 1.8 \\
\hline $17-18$ & ID & 8 & 41.3 & 16.1 & 10.0 & 11.1 & 16.8 & 3.6 & 4.5 & 2.4 & 1.7 \\
\hline $19-20$ & IA & 8 & 34.8 & 11.5 & 5.3 & 9.0 & 13.8 & 3.7 & 4.3 & 2.4 & 1.7 \\
\hline $21-22$ & IA & 8 & 41.0 & 15.6 & 4.8 & 10.0 & 15.3 & 4.0 & 4.5 & 2.6 & 1.7 \\
\hline $23-24$ & IA & 7 & 40.6 & 14.9 & 9.4 & 11.0 & 16.4 & 3.9 & 4.4 & 2.6 & 1.8 \\
\hline $25-26$ & $\mathrm{BC}$ & 8 & 42.3 & 18.5 & 3.6 & 9.4 & 13.5 & 3.8 & 4.5 & 2.5 & 1.7 \\
\hline $27-28$ & Sask & 7 & 34.1 & 17.0 & 5.4 & 10.7 & 15.0 & 4.0 & 4.5 & 2.6 & 2.0 \\
\hline $33-34$ & $\mathrm{KS}$ & 8 & 60.9 & 24.5 & 5.8 & 12.6 & 19.5 & 4.0 & 4.7 & 2.6 & 1.7 \\
\hline $35-36$ & MI & 8 & 34.9 & 11.3 & 7.9 & 9.0 & 13.3 & 3.8 & 4.4 & 2.5 & 1.8 \\
\hline $37-38$ & $\mathrm{MN}$ & 8 & 42.0 & 14.4 & 8.0 & 10.8 & 16.0 & 3.7 & 4.4 & 2.4 & 1.6 \\
\hline $39-40$ & $\mathrm{NE}$ & 8 & 38.1 & 18.4 & 4.4 & 10.9 & 15.5 & 3.7 & 4.5 & 2.5 & 1.7 \\
\hline $49-50$ & NV & 6 & 38.3 & 19.5 & 8.7 & 12.3 & 16.0 & 3.8 & 4.7 & 2.7 & 1.5 \\
\hline $51-52$ & NV & 8 & 39.0 & 12.9 & 5.0 & 10.3 & 15.8 & 3,7 & 4.4 & 2.3 & 1.9 \\
\hline $53-54$ & ND & 8 & 39.9 & 12.4 & 5.4 & 10.3 & 15.5 & 4.1 & 4.8 & 2.6 & 1.6 \\
\hline $55-56$ & ND & 8 & 34.1 & 10.4 & 9.9 & 8.8 & 15.3 & 3.6 & 4.4 & 2.3 & 1.8 \\
\hline $65-66$ & ND & 8 & 43.4 & 10.5 & 8.5 & 10.6 & 16.4 & 3.7 & 4.6 & 2.4 & 1.6 \\
\hline 67-68 & OR & 8 & 36.3 & 15.1 & 6.9 & 10.4 & 17.0 & 3.7 & 4.6 & 2.6 & 1.8 \\
\hline $69-70$ & OR & 8 & 38.5 & 13.5 & 11.5 & 11.6 & 21.1 & 3.8 & 4.9 & 2.6 & 1.9 \\
\hline 71-72 & UT & 8 & 40.9 & 15.8 & 9.8 & 11.4 & 18.6 & 3.8 & 4.4 & 2.6 & 1.7 \\
\hline Avera & & & 40.9 & 15.0 & 6.7 & 10.5 & 16.1 & 3.8 & 4.5 & 2.5 & 1.7 \\
\hline
\end{tabular}

${ }^{a}$ Location.

${ }^{\mathrm{b}}$ Observations.

${ }^{c}$ Terminal rays.

${ }^{\mathrm{d}}$ Axillary rays.

${ }^{\mathrm{e}}$ Number of leaves $/ 4 \mathrm{~cm}$ of stem at the midcauline point.

Middle cauline leaf measurements were the most useful taxonomic criteria. RadcliffeSmith's key was used in this study of North American leafy spurge and for the most part used leaf characteristics to differentiate the species. It divided the leafy spurge complex according to five general cauline leaf shape descriptions: a) leaves cordate at the base, b) leaves linear and densely clustered, c) leaves oblanceolate or narrowly oblanceolateoblong, rounded at the apex, broadest above the middle, and cuneate-attenuate at the base, d) leaves linear, lanceolate or oblong, broadest at or below the middle or of some- 
what uniform breadth for most of their length, and e) leaves broadest below the middle, rounded or cuneate rounded at the base.

Plants with cauline leaves, which are cordate at the base, are referable to E. agraria M. Bieb. This plant was first recognized in the United States in 1971 from a collection in Jefferson County, Nebraska. It has now been reported in Marshall County, Kansas and in Converse and Platte Counties in Wyoming (4). The plant is similar to other leafy spurge plants except the leaf is very broad with a prominent midvein and cordate base. In 1981, it bloomed 1 to 2 weeks earlier than other plants in the nursery. E. agraria has the potential to become a very troublesome weed because of its reproductive capability, which is similar to the more common leafy spurge plants of the Midwest.

Plants with cauline leaves which are narrowly linear and are densely clustered on the axillary leafy shoots describes E. cyparissias L. The densely clustered leaves give the socalled pine-like appearance. No seed production was observed but it was apparent that it had great potential to spread by root. Only a few root sections were transplanted into each tube in 1980, but by 1981 stem numbers were over 240 in one tube and 160 in the other. The leaf characteristics of E. agraria and E. cyparissias make them very easy to identify. However, many natural hybrids have occurred where E. agraria or E. cyparissias have been found to be one of the parents. These hybrids add to the confusion of identification.

Plants with cauline leaves oblanceolate or narrowly oblanceolate-oblong, rounded at the apex, broadest above the middle, cuneate-attenuate at the base, and leaves which are usually 5 to $10 \mathrm{~mm}$ broad keys to the true E. esula L. Only the plants from Austria fit this description. The leaf consisted of a broad, rounded upper portion, which then tapered to an attenuate base. The apical, middle, and basal measurements were 5.3, 5.0, and $3.1 \mathrm{~mm}$, respectively, for tube numbers 1 and 2 and 5.6, 6.3, and $2.9 \mathrm{~mm}$, respectively, for tube numbers 3 and 4 . No other specimens were observed in the nursery material, which keyed to E. esula. Radcliffe-Smith believed it was present in many provinces of Canada and throughout the United States but it was not as prevalent as Bakke (1) indicated.

Looking at general leaf shape, and not specifically leaf width, we easily identified the rest of the nursery material. Table 5 is an evaluation of the species for plants established 3 years.

Leaves which were linear, lanceolate or oblong, broadest at or below the middle, or of somewhat uniform breadth for the most of their length describe, in general, the other 7 species in the key. Plants with stems branched from the base with numerous sterile branches, leaves narrowly linear and usually less than $1.5 \mathrm{~mm}$ broad, keys to E. uralensis Fisch. ex Link. Tube numbers 9 and 10 from Crook County, Wyoming may approach $E$. uralensis. Leaves averaged 3.9, 5.8, and $6.0 \mathrm{~mm}$ for apical, middle, and basal leaf widths, respectively. The widths were much greater than indicated by Radcliffe-Smith; however, when coupled with their long leaves, $75.3 \mathrm{~mm}$, it gives them a very linear appearance. Branching was not observed from the base of the stem, which was the main criterion used by Radcliffe-Smith. However, many of the nursery plants exhibited basal branching late in the season. Thus, the Wyoming location may be E. uralensis if basal branching later in the season is typical of E. uralensis. Plants with stems which are sparingly branched from the middle or above, leaves oblong to elliptic-oblong, obtuse or rounded at the apex and usually 1.5 to $2.0 \mathrm{~mm}$ broad keys to E. androsaemifolia Willd. No specimens were seen of E. androsaemifolia.

Page 11 of 14 
Table 5. Species evaluation of the leafy spurge complex of plants established 3 years.

\begin{tabular}{lll}
\hline Tube & Location & \multicolumn{1}{c}{ Specific evaluation } \\
\hline $1-2$ & Aust & E. esula \\
$3-4$ & Aust & E. esula \\
$5-6$ & ID & E.pseudovirgata \\
$7-8$ & ID & E. $\times$ pseudovirgata \\
$9-10$ & WY & E.uralensis \\
$13-14$ & Sask & E. $\times$ pseudovirgata \\
$15-16$ & Man & E. $\times$ pseudovirgata \\
$17-18$ & ID & E. $\times$ pseudovirgata \\
$19-20$ & IA & E. $\times$ pseudovirgata \\
$21-22$ & IA & E. $\times$ pseudovirgata approaches $E$. waldsteinii \\
$23-24$ & IA & E. $\times$ pseudovirgata \\
$25-26$ & BC & E. $\times$ pseudovirgata \\
$27-28$ & Sask & E. $\times$ pseudovirgata \\
$33-34$ & KS & E. $\times$ pseudovirgata \\
$35-36$ & MI & E. $\times$ pseudovirgata \\
$37-38$ & MN & E. $\times$ pseudovirgata approaches $E$. waldsteinii \\
$39-40$ & NE & E. $\times$ pseudovirgata \\
$49-50$ & NV & E. $\times$ pseudovirgata \\
$51-52$ & NV & E. $\times$ pseudovirgata \\
$53-54$ & ND & E. $\times$ pseudovirgata \\
$55-56$ & ND & E. $\times$ pseudovirgata approaches $E$. waldsteinii \\
$65-66$ & ND & E. $\times$ pseudovirgata \\
$67-68$ & OR & E. $\times$ pseudovirgata approaches $E$. waldsteinii \\
$69-70$ & OR & E. $\times$ pseudovirgata \\
$71-72$ & UT & E. $\times$ pseudovirgata \\
\hline & &
\end{tabular}

Cauline leaves broadest at or below the middle, tapered towards the apex and somewhat narrowed towards the base described three other species, further separated according to leaf width. Cauline leaves commonly $2 \mathrm{~mm}$ broad keys to E. gayeri Boros \& Soó, cauline leaves commonly 4 to $5 \mathrm{~mm}$ broad keys to E. pseudovirgata (Schur) Soó, and cauline leaves commonly more than $5 \mathrm{~mm}$ broad keys to E. boissieriana $\times$ esula. No material was seen which would key to E. gayeri. All leaf widths were greater than $4.4 \mathrm{~mm}$ and averaged $6.6 \mathrm{~mm}$. It was very unlikely that the rest of the nursery material would be E. boissieriana $\times$ esula even though the majority of it would key to this species. This hybrid, as reported by Radcliffe-Smith, has not been found in Europe but has been recognized among material from only a few provinces and states in North America. This would leave only one species, E. $\times$ pseudovirgata, in which the majority of the nursery material would seem to fit. E. $\times$ pseudovirgata is an esula-waldsteinii hybrid. Some of its synonomy includes E. virgata Wald. \& Kit., E. intercedens Podp., E. virgata Wald. \& Kit. forma esulifolia Thell., E. podperae Croiz., and E. jucula Prod. Dunn and RadcliffeSmith (9) showed the wide distribution of the plant in relation to other plants in the leafy spurge complex and its rapid spread throughout the Midwest, Northeast, and Canada. The averages across all locations for apical, middle and basal leaf widths were 5.0, 6.6, and $5.0 \mathrm{~mm}$, respectively. Leaf lengths averaging $61.2 \mathrm{~mm}$ would give a general appearance to what Radcliffe-Smith described as leaves broadest at or below the middle, tapering to- 
wards the apex and narrowing somewhat towards the base. It would seem realistic, then, that the majority of the nursery plants would be classified as E. × pseudovirgata.

The two final species are described as having cauline leaves which are broadest below the middle, rounded or cuneate rounded at the base. E. waldsteinii (Sojak) A. Radcliffe-Smith comb. nov. is further described as having cauline leaves which are linear, lanceolate and usually cuspidate-acuminate. E. boissieriana (Worn.) Prokh. has cauline leaves lanceolate and usually obtuse but sometimes mucronulate. No specimens had the broadest part of the leaf below the middle. However, some may approach the E. waldsteinii as in tube numbers 21 and 22 with apical, middle, and basal leaf widths of 5.9, 7.9, and $6.4 \mathrm{~mm}$, respectively; tubes 37 and 38 with widths of $6.3,8.9$, and $7.3 \mathrm{~mm}$; tubes 55 and 56 with widths of 3.8, 5.1, and $4.9 \mathrm{~mm}$; and tubes 67 and 68 with widths of 6.4, 9.6, and $7.0 \mathrm{~mm}$. Plant from root sections received from the Ukraine, growing in the greenhouse, have the characteristics to be E. waldsteinii, Radcliffe-Smith has seen material of E. waldsteinii from many provinces and states but does not consider it to be as serious a pest as the hybrid E. $\times$ pseudovirgata.

The problem surrounding the leafy spurge complex has not been completely resolved. However, in studying the nursery material and using Radcliffe-Smith's key (14), some conclusions can be made. The nursery material represented a large degree of variability, which could reflect a normal field situation. Variability among the plants was seen from season to season as well as within a season. Some variability was noted in plants within the same tube as well. Thus, even though differences may appear to exist they may not be representing true species differences.

The early taxonomists who recognized the majority of the population as either $E$. esula or E. virgata were not completely inaccurate. Bakke (1), Wheeler (16), Hanson and Rudd (11), Moore (12), and Richardson (15) classified the variable population as one species. The criteria they used differentiated whether it should be called E. esula or $E$. virgata. The majority of the nursery material also represented one species, E. × pseudovirgata, according to Radcliffe-Smith's key (14), which used a different set of criteria.

The Austrian sources represented the true E. esula. After seeing this plant and its leaf characteristics, there should be no indecision between it and other plants in the leafy spurge complex. Since E. $\times$ pseudovirgata is a hybrid between esula and waldsteinii, it would seem realistic that a high degree of variability would exist. Some populations could reflect more of the esula type, others may reflect more of the waldsteinii type while the bulk of the population falls somewhere in between. The main criteria for keying these plants was midcauline leaf shape. No other characteristics seemed to have as much taxonomic value. However, they are important when describing the general appearance of the plant.

The taxonomy of North American leafy spurge complex is a very important aspect of biological control. Without the correct identification of these plants, its place of origin cannot be determined, and hence, the collection of biological control agents may not be host specific. Success or failure may depend on its accuracy. It is hoped that this study has helped to provide knowledge of the leafy spurge complex plants in describing and classifying the variable population in North America. 


\section{Acknowledgments}

The authors wish to express thanks to all people who contributed plant material for the nursery. Without their cooperation, this study could not have been possible. We would also like to thank P. H. Dunn and R. L. McGregor for personal evaluations of the nursery.

\section{Literature cited}

1. Bakke, A. L. 1936. Leafy spurge, Euphorbia esula L. Iowa Agr. Exp. Sta. Bull. 198:207-246.

2. Batho, G. 1931. Leafy spurge. Manitoba Dep. of Agr. Imm. Cir. 106. 4 pp.

3. Britton, N. L. 1921. The leafy spurge becoming a pest. J. NY Bot. Gard. 22:73-75.

4. Brooks, R. E. and R. L. McGregor. 1981. Vascular flora of Kansas; new records and notes for 1980. Tech. Publ. State Biol. Surv. Kansas 10:1-6.

5. Croizat, L. 1945. Eupborbia esula in North America. Amer. Midl. Nat. 33:231-243.,

6. Croizat, L. 1947. Euphorbia intercedens Podp., a homonym. Amer. Midl. Nat. 37:801-802.

7. Dunn, P. H. 1979. The distribution of leafy spurge (Euphorbia esula) and other weedy Euphorbia spp. in the United States. Weed Sci. 27:509-516.

8. Dunn, P. H. 1979. Probable origins of leagy spurge (Euphorbia esula L.) in North America. Abs. Weed Sci. Soc. Am. p. 81.

9. Dunn, P. H. and A. Radcliffe -Smith. 1980. The variability of leafy spurge (Euphorbia spp.) in the United States. Nor. Cen. Weed Cont. Conf. Res. Rep. Vol. 37:48-5 3.

10. Groh, H. 1935. Leafy spurge - Euphorbia esula or virgata. Sci. Agr. 15:701-703.

11. Hanson, H. C. and V. E. Rudd, 1933. Leafy spurge life history and habits. Agr. Exp. Sta., ND Agr. Coll. Bull. 266. 23 pp.

12. Moore, R. J. 1958. Cytotaxonomy of Euphorbia esula in Canada and its hybrid with Euphorbia cyparissias. Can. J. Bot. 36:547559.

13. Morton, C. V. 1937. The correct name of leafy spurge. Rhodora. 39:49-50.

14. Radcliffe-Smith, A. 1982. New combinations in the genus Euphorbia III. Kew Bull. 36(2):216.

15. Richardson, J. W. 1968. The genus Euphorbia of the high plains and prairie plains of Kansas, Nebraska, South and North Dakota. Univ. Kan. Sci. Bull. Vol. XLVIII, No. 31:45-112.

16. Wheeler, L. C. 1939. A miscellany of the new world Euphorbiaceae-11. Contr. Gray Herb. 127:48-78. 